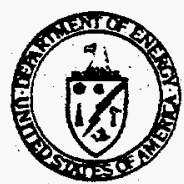

\title{
RCRA Corrective Action Corrective Measure Study
}

BACKGROUND: The 1984 paseage of the Hazardous and Solid Waste Amendments (HSwA) to the Resource Conservation and Recovery Act (RCRA) strengthened the Environmental Protwetion A pency's (EPA's) ebillity to require harandous

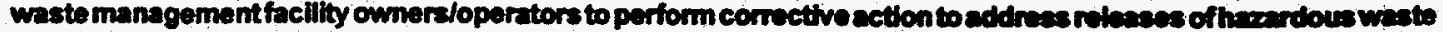

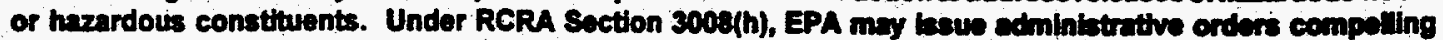
corrective action at interim sthus facilfies. Under RCRA section 3004(U), amy permit baved to a trutmont,

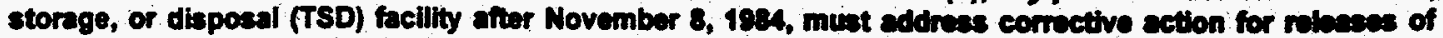
hazardous weste or hazardous constituents from any solid weste manogomont unit (swinu) at the feclity. Under RCRASection $3004(v)$, EPA may compela TSD facilty owmerloperater to remediate relaseses that migrate beyond the facility's boundary.

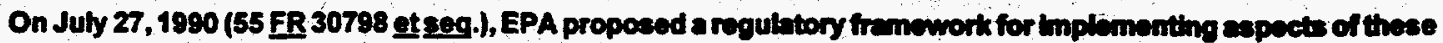
statutory changes. This framework, proposed under 10 CFR subparts, establishes ruquinementi for conducting corrective action investigations and for evaluating, eelocting, and implemsenting appropriate comectwe action remedies at SWMUs. The proposed regulations define a SWWU broady to include any discemible unte at which solid wastes were placed at any time, irrespective of whether the unitwas intended for the management of solid or hazardous waste. Some States and EPA Regions are currently using the propoced ropulations as the basis for the performance of corrective action at permittod and interim stitus bOE fecilities.

The proposied corrective action framework involves four phases: RCRAFacilly Aaseasmont (RFA), RCRA Facility Investigation (RFI), Corrective Measures Study (CMS), and Corrective Measures Inplementation (CMi). This Information Brief provides an overview of the CMS process and is one of a series of Information Briefs on RCRA Corrective Action.

STATUTE: RCRA Sections 3008(h), 3004(u), and 3004(v).

REGULATIONS: Proposed 40 CFR 264, Subpart S (55 FR 30798 et seq.; Juby 27, 1990).

REFERENCE:

1. "RCRA Corrective Action Program Guide - Interim Guidance," U.S. Department of Energy, Office of Environmental Guidance, RCRACERCLA Division; Guidance Manual, DOEJEH-0323, May 1993.

2. "RCRA Corrective Action Permit Requirements and Modifications Under Proposed Subpart S Rule," U.S. Department of Energy, Office of Environmental Guidance, RCRACERCLA Division, Information Brief, EH231-02310793 (July 1993).

3. "CAMUTTU Final Rule issued," U.S. Department of Energy, Office of Environmental Guidance, RCRA CERCLA Dlvision, Regulatory Bülletin, May 12, 1993.

4. "A Comparison of the RCRA Corrective Action and CERCLA Remedial Action Process," U.S. Department of Energy, Office of Environmental Guidance, RCRACERCLA Division, públication DOEJEH-0365, February 1994.

\section{What is a CMS?}

Preparation of a CMS is the third phase in the execution of corrective action under RCRA. It is prepared by the facility owner/ operator with guidance from EPA or an authorized State. If required to perform a CMS, an owner/operator identifies, evaluates, and recommends specific measures that will remediate releases based on a thorough evaluation of applicable data and corrective measures technologies. The CMS must be conducted in accordance with the schedule of compliance specified in the facility permit [proposed 40 CFR 270.34] or in an administrative order issued under Section 3008(h) of RCRA.

A CMS is analogous to a feasibility study conducred for iemedial actions under the Comprehensive Environmental Response Compensation and Liability Act (CERCLA) (see Reference 4). The procedural and substantive regulatory requirements associated with the performance of a CMS are in proposed 40 CFR 264.520-264.524.
What is the objective of a CMS?

The objective of a CMS is to identify and evaluate alternative corrective measures and to recommend a corrective measure(s) for remediation of the contaminated site. To achieve this objective, the CMS should consider all of the necessary data and information to evaluate the proposed altematives.

\section{What triggers the requirement to perform a CMS?}

An owner/operator may be required to perform a CMS under two different sets of circumstances: First, a CMS must be performed if the regulator determines that: concentrations of hazardous constituents in ground water in an aquifer, surface water, soils, or air exceed action levels set for these constituents; and there is reason to believe that the hazardous constituents were released from a SWMU at the facility [proposed 40 CFR 264.520(a)]. 
Action levels are defined in proposed 40 CFR 254.521 as mediaspecific health- and environmental-based contaminant concentrations considered protective of human health and the environment.

Second a CMS must be performed when hazardous constituent concentrations are below action levels if the regulator determines that:

D concentrations of hazardous constituents may pose a threat to human health or the environment, given site-specific exposure conditions; and

D there is reason to believe that the hazardous constituents were released from a SWMU at the facility [proposed 40 CFR 264.520(b)].

\section{What is the scope of a CMS?}

Regulations defining the scope of a CMS are designed to be flexible, allowing the regulator to tailor the scope and approach used by the owner/operator to the extent and nature of contamination at the facility [55 FR 30821; July 27, 1990]. The regulator may require that a CMS include any of the following types of analyses, or other analyses as appropriate.

- An evaluation of performance reliability. ease of implementation. and potential impacts of one or more potential remedies.

- An assessment of the effectiveness of potential remedies in achieving adequate control of sources and cleanup of the hazardous waste and hazardous waste constituents released from SWMUs.

- An assessment of the time required to begin and complete the remedy:

\section{An assessment of the costs of remedy implementation.}

- An assessment of institutional requirements (e.g., State or local permit requirements) which may substantially affect implementation of the remedy [proposed 40 CFR 264.522].

\section{What reports are associated with the performance of a CMS?}

The regulator may require that the owner/operator submit periodic reports during the conduct of a CMS. Based on the information in these reports, the regulator may require the owner/operator to modify the scope of the CMS [proposed 40 CFR 264.524(a)]. Upon completion of the CMS, the owner/operator must submit a report describing and evaluating the remedies assessed in relation to the criteria used by the regulator in selecting a remedy (see below) [proposed 40 CFR 264.524(b)].

\section{What happens once a CMS is completed?}

Based on the CMS results, the owner/operator may recommend the selection of one of the potential remedies analyzed. The regulator may accept or reject this recommendation, or ask for additional information [proposed 40 CFR 264.524(c)]. Once the final CMS report has been submitted, the regulator selects a remedy and appropriate changes must be made to the facility permit (or administrative order) to implement the remedy. Reference 2 contains more information about the permit modifications associated with CMII

\section{What criteria does the regulator use to select a remedy?}

The regulator is required to select a remedy that meets the following criteria:

- It must be protective of human health and the enviroment.

D It must attain applicable medis cleanup standards.

D It must control the source(s) of releases so as rectuce or eliminate further releases of hazardous wastes and havardous constituents that may pose a threat to human health and the emviromment.

I It must comply with other aspects of the proposed Subpart S regulations regarding management of wastes [proposed $40 \mathrm{CFR}$ 264.525(a)].

In evaluating alternative remedies, the regulator is required to consider: long-term reliability and effectiveness; degree of rectuction of toxicity, mobility, or volume; short-term effectiveness; implementability; and cost [proposed 40 CFR 264.525(b)].

\section{What are some of the other factors considered by the regulator in the remedy selection process?}

Other factors considered in the remedy selection process include the schedule for implementing corrective measures, the designation of corrective action management units (CAMUs) and temporary units (TUs), the need for phased or conditional remedies, and the ability of alternative remedies to meet media cleanup standards. Chapter 5 of DOE's RCRA Corrective Action Program Guide (Reference 1) provides additional information about these aspects of the remedy. selection process. DOE's regulatory bulletin (Reference 3 ) on the issuance of the CAMU/TU final rule describes the CAMU/TU designation process and the advantages of having certain remediation waste management areas designated as CAMUs and certain tanks and containers designated as TUs by the regulator.

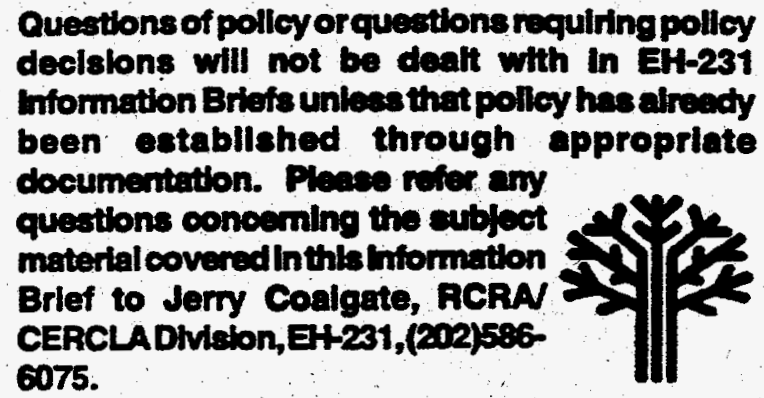

\section{C}

\section{.}

